\title{
Pembuatan pakan alami untuk pengembangan kepiting cangkang lunak di Desa Pulau Cawan Kecamatan Mandah kabupaten Indragiri Hilir
}

\author{
T. Ersti Yulika Sari*, Usman, \& Nur Asiah \\ Fakultas Perikanan dan Ilmu Kelautan, Universitas Riau \\ * t.ersti@lecturer.unri.ac.id
}

\begin{abstract}
Abstrak. Kepiting soka adalah kepiting bakau yang dibudidayakan dan dilakukan pemanen disaat molting sehingga cangkangnya menjadi lunak dan mudah untuk dikonsumsi. Tujuan dari pengabdian ini adalah untuk meningkatkan pendapatan masyarakat Desa Pulau Cawan, Kecamatan Mandah, Kabupaten Indragiri Hilir melalui budidaya kepiting soka dengan memperkenalkan teknik budidaya yang ramah lingkungan, namun dapat menghasilkan nilai tambah dari segi peningkatan ekonomi keluarga melalui budidaya kepiting soka salah satunya dengan pelatihan pembuatan pakan alami. Hal ini berdasarkan informasi dari masyarakat yang belum pernah mendapatkan pelatihan tentang pembuatan pakan. Melalui program desa binaan yang dilakukan, diberikan ilmu dan teknologi tentang teknik pembuatan pakan alami dari air kapur dan ekstrak bayam sebagai pengganti vitomolt yang harganya cukup mahal. Metode yang digunakan dalam kegiatan pengabdian Desa Binaan ini adalah ceramah, diskusi dan praktek langsung di POKDAKAN dimulai dengan persiapan ekstrak bayam, ikan rucah, air kapur, pencampuran serta penjemuran. Hasil evaluasi terhadap peserta penyuluhan menunjukkan 24 orang peserta belum pernah mengenal tentang pembuatan pakan alami dari ekstrak bayam sebagai pakan kepiting soka. Setelah mengikuti kegiatan pelatihan ini terjadi peningkatan pengetahuan tentang cara pembuatan pakan sebesar $86,96 \%$. Penilaian mitra terhadap pelaksanaan kegiatan ini adalah: $52,17 \%$ sangat setuju pembuatan pakan ini dapat dilakukan secara mandiri; 52,17\% sangat setuju pemberian air kapur dan ekstrak bayam terhadap campuran pakan buatan ikan rucah berpengaruh terhadap percepatan proses molting pada kepiting dan tidak berpengaruh terhadap kelulushidupan kepiting; $60,87 \%$ sangat setuju dapat menjadi alternatif mata pencaharian; $65,22 \%$ sangat setuju proses molting pada budidaya kepiting cangkang lunak sama dengan saat kepiting diberi vitomolt yaitu 20 hari.
\end{abstract}

Kata Kunci: pakan alami, budidaya kepiting, cangkang lunak, Pulau Cawan

\begin{abstract}
Mud crabs are mangrove crabs that are cultivated and harvested when molting so that their shells become soft and easy to consume. The purpose of this activity is to increase people's income in Desa Pulau Cawan, Kecamatan Mandah, Kabupaten Indragiri Hilir, through soft shell crab cultivation by introducing environmentally friendly cultivation techniques, but it can produce added value in terms of improving the family's economy through soft-shell crab cultivation, one of which is training in making natural feed. This is based on information from farmers who have never received training on feed manufacturing. Through the foster village program, knowledge and technology are given about techniques for making natural feed from lime water and spinach extract as a substitute for vitamalt which is quite expensive. The methods used in the Community activities of the foster Village are lectures, discussions and direct practice with POKDAKAN, starting with the preparation of spinach extract, trash fish, lime water, mixing and drying. The results of the evaluation of the counseling participants showed that 24 participants had never known about making natural feed from lime water and spinach extract as soka crab feed. After participating in this training activity there was an increase of $86.96 \%$ in knowledge about how to make natural feed. The partner's assessment of the implementation of this activity is $52.17 \%$ strongly agree that this natural feed can be made independently; $52.17 \%$ strongly agree that giving lime water and spinach extract to the artificial feed mixture of trash fish has an effect on the acceleration of the molting process in crabs and does not affect the survival of crabs; $60.87 \%$ strongly agreed that it could be an alternative livelihood; strongly agree that the molting process in soft-shell crab cultivation is the same as when the crabs are given a vitamolt, which is 20 days.
\end{abstract}

Keywords: natural feed, crab cultivation, soft shell, Pulau Cawan

To cite this article: Sari, T. E. Y., Usman., \& N. Asiah. 2020. Pembuatan pakan alami untuk pengembangan kepiting cangkang lunak di Desa Pulau Cawan Kecamatan Mandah kabupaten Indragiri Hilir. Unri Conference Series: Community Engagement 2: 386-392. https://doi.org/10.31258/unricsce.2.386-392

(C) 2020 Authors

Peer-review under responsibility of the organizing committee of Seminar Nasional Pemberdayaan Masyarakat 2020 


\section{PENDAHULUAN}

Desa Pulau Cawan, Kecamatan Mandah, Kabupaten Indragiri Hilir merupakan sebuah desa yang memiliki sumberdaya kepiting soka yang cukup potensial. Kepiting soka merupakan salah satu organisme perairan bernilai ekonomis tinggi dan diminati masyarakat, baik di pasaran dalam negeri maupun luar negeri karena rasa daging yang lezat dan bernilai gizi tinggi. Kelompok kepiting tersebut, hidup terutama pada pantai yang ditumbuhi mangrove, perairan dangkal dekat hutan mangrove, estuari dan pantai berlumpur, sehingga sering disebut juga mud crab atau mangrove crabs. Kepiting bakau (Scylla serrata) merupakan salah satu komoditas perikanan pantai, khususnya di hutan bakau (mangrove) (Kanna, 2002).

Komoditas perikanan ini merupakan produk ekspor yang memiliki harga relatif tinggi dibanding kepiting berkulit keras. Kepiting cangkang lunak diekspor ke Amerika, Jepang, Hongkong, Taiwan, Malaysia, dan sejumlah negara di kawasan Eropa (Fujaya et al., 2008). Walaupun secara ekonomis budidaya kepiting cangkang lunak kelihatan menguntungkan, namun sebagian besar pengusaha kepiting lunak tidak mengalami kontinuitas usaha. Periode pemeliharaan yang lama dan waktu molting yang tidak serentak menjadi kendala utama dalam usaha ini. Periode pemeliharaan yang lama menyebabkan biaya pakan dan operasional menjadi tinggi, sedangkan waktu molting yang tidak serentak mengharuskan pengawasan yang lebih ketat selama pemeliharaan sehingga kurang efisien dari segi waktu dan tenaga (Ansari dan Sulaeman, 2010).

Permasalahan dalam pengembangan budidaya kepiting bakau cangkang lunak di Pulau Cawan adalah keterbatasan biaya dalam penyediaan vitomolt, yang digunakan dalam percepatan pergantian cangkang dan pengadaan pakan yang sangat dibutuhkan untuk kelangsungan hidup kepiting. Mendukung upaya budidaya kepiting juga perlu mempertimbangkan pakan yang digunakan. Untuk dapat mengurangi biaya yang ada, kita dapat memberikan pakan alami ataupun pakan yang diolah sendiri. Dengan pengolahan pakan sendiri, tentu lebih banyak keuntungan yang akan didapatkan. Mulai dari harga yang terjangkau serta pengolahan yang dapat dipastikan higienis. Permasalah tersebut dapat diatasi dengan memperkenalkan pembuatan pakan alami dari air kapur, ekstrak bayam dan ikan rucah.

Kegiatan Program Desa Binaan yang dilakukan Tim Lembaga Penelitian dan Pengabdian Universitas Riau terhadap pembudidaya kepiting cangkang lunak di Desa Pulau Cawan Kecamatan Mandah Kabupaten Indragiri Hilir bertujuan untuk memberikan pembelajaran bagi petambak kepiting untuk memperoleh pakan alami yang lebih murah dalam pengembangan teknik produksi kepiting bakau cangkang lunak yang efektif dan efisien yang dapat diaplikasikan oleh pembudidaya kepiting yang akan dikembangkan di Desa Pulau Cawan Kecamatan Mandah Kabupaten Indragiri Hilir.

\section{METODE PELAKSANAAN}

Kegiatan pembinaan kelompok petani budidaya melalui kegiatan teknologi budidaya kepiting cangkang lunak dan pembuatan pakan berbasis bahan lokal pada budidaya kepiting bakau di desa Pulau Cawan Kecamatan Mandah ini dilakukan selama 6 bulan, mulai dari pendekatan kepada masyarakat sasaran sampai dengan pelaksanaan kegiatan. Metode penerapan IPTEKS kepada mitra dilakukan selama 3 tahun, tahun pertama kegiatan yang sudah dilakukan adalah: Memberikan penyuluhan mengenai teknik budidaya kepiting cangkang lunak dengan pemberian vitamolt untuk mempercepat molting, peluang usaha dan pengolahan pasca panen. Tahun kedua kegiatan yang sudah dilakukan adalah pembuatan pembuatan tambak kepiting dan demplot. Dan pada tahun ketiga adalah produksi kepiting soka dan pembuatan pakan alami dari ekstrak bayam sebagai pengganti vitamolt.

Kegiatan yang dilakukan pada tahun ketiga ini adalah: 1). Peningkatan produksi kepiting melalui aplikasi inovasi teknologi yang didapatkan pada tahun kedua pada skala massal, yaitu pembuatan kolam baru dengan ukuran yang lebih luas; 2). Pembuatan keramba kepiting yang berbahan bambu, 3). Pembuatan pakan alami dengan campuran ekstrak bayam, air kapur dan ikan rucah. Sedangkan rencana kegiatan selanjutnya adalah: Peningkatan keterampilan pembudidaya dalam penanganan pasca panen produk hasil budidaya ikan dan pengemasan sampai pemasarannya.

Kegiatan yang dilakukan pada tahun ketiga ini dimulai dengan melakukan pertemuan dan diskusi dengan mitra tentang rencana kegiatan yang akan dilaksanakan, melibatkan Kepala Desa, POKDAKAN Pulau Cawan, POKDAKAN Pantai Solop, Karang Taruna, Dinas Perikanan dan Kelautan Kabupaten Indragiri Hilir dan mahasiswa KKN. Kemudian dilanjutkan dengan kegiatan: 1). Pembuatan kolam baru dengan aplikasi tambak silvofishery 2). Pengapuran tambak. 3). Pembuatan keramba berbahan dasar bambu, 4) Pembuatan pakan alami dari campuran ekstrak bayam, air kapur dan ikan rucah 
Untuk menilai ketercapaian tujuan kegiatan, dilakukan evaluasi. Jenis evaluasi yang dilakukan adalah: 1) Evaluasi Proses dan 2) Evaluasi Peningkatan Pengetahuan. Evaluasi proses dilakukan selama proses penyuluhan berlangsung, mulai dari penyajian materi (teori) sampai kegiatan praktek. Disini dilihat keseriusan peserta mengikuti serangkaian kegiatan tersebut dan diskusi-diskusi yang berkembang. Evaluasi peningkatan pengetahuan dilakukan dengan memberikan pre-test dan post-test. Hasil dari pre-test dibandingkan dengan post-test, apakah ada penambahan pengetahuan atau sebaliknya. Peningkatan pengetahuan ditampilkan dalam bentuk persentase $(\%)$.

Masyarakat yang dijadikan sasaran kegiatan sekaligus Mitra Program Desa Binaan di Desa Pulau Cawan adalah 24 orang pembudidaya kepiting yang berada dalam wadah Kelompok Pembudidaya Ikan (POKDAKAN) Pulau Cawan dan Pantai Solop. Anggota POKDAKAN Pulau Cawan dan Pantai Solop menjadikan budidaya kepiting soka sebagai mata pencaharian sampingan, sedangkan mata pencaharian utamanya adalah nelayan penangkap ikan di laut.

\section{HASIL DAN KETERCAPAIAN SASARAN}

\section{Potensi pengembangan (pemberdayaan) masyarakat}

Usaha penangkapan kepiting banyak dilakukan oleh nelayan di Kecamatan Mandah, sehingga banyak hasil tangkapan yang tidak terserap pasar karena belum mencapai ukuran konsumsi. Salah satu usaha agar hasil tangkapan nelayan tersebut dapat terserap dan meningkatkan nilai jualnya dari kepiting adalah dengan melakukan usaha pembesaran kepiting soka. Kepiting soka adalah kepiting bakau yang dibudidayakan dan dilakukan pemanenan disaat molting sehingga cangkangnya menjadi lunak dan mudah untuk dikonsumsi. Dengan melakukan usaha ini maka dapat meningkatkan harga jual kepiting. Upaya untuk menghasilkan kepiting soka dapat dilakukan dengan merangsang kepiting tersebut untuk molting (ganti kulit). Penggunaan ekstrak bayam (vitomolt) dapat mempercepat proses molting dan berwawasan lingkungan. Permasalahan utama bagi POKDAKAN adalah tingginya harga vitamolt serta ketersediaan pakan, sehingga dikhawatirkan akan menghambat pengembangan usaha budidaya kepiting soka. Tingginya harga vitamolt dapat diatasi dengan melakukan pembuatan pakan alami dari ekstrak bayam, air kapur dan ikan rucah. Penambahan ikan rucah pakan alami budidaya bertujuan untuk meningkatkan protein pakan alami, sehingga dapat menggantikan vitamolt, mengurangi penggunaan pakan buatan dan biaya pembelian pakan menjadi rendah.

Berdasarkan penjabaran di atas kegiatan budidaya kepiting soka merupakan suatu kegiatan usaha yang memiliki prospek yang baik dan layak untuk dikembangkan ditinjau dari aspek pasar, aspek teknis dan aspek finansial. Ditinjau dari aspek pasar usaha budidaya kepiting soka ini layak karena potensi pasar yang besar. Ditinjau dari aspek teknis usaha budidaya kepiting soka ini dapat dikembangkan karena ketersediaan bahanbahan pembuat kolam yang sederhana dengan bahan yang mudah didapat dan harganya terjangkau. Tingkat teknologi yang digunakan umumnya juga masih sederhana sehingga dapat diterapkan dalam pengelolaan usaha di tingkat nelayan pembudidaya, kemudian sarana dan prasarana pendukung secara umum mudah didapat atau bisa dimodifikasi, dan nilai tambah produk dapat ditingkatkan melalui teknis budidaya yang dapat diterapkan di tingkat nelayan pembudidaya. Hasil survey dan wawancara dengan penduduk setempat juga menunjukkan bahwa mereka berminat untuk melakukan budidaya kepiting soka dengan sistem budidaya menggunakan pakan alami karena dapat diterapkan di lahan yang relatif tidak terlalu besar dan biaya pembelian pakan komersial dapat ditekan.

\section{Solusi pengembangan (pemberdayaan) masyarakat}

Solusi yang dapat dilakukan agar usaha budidaya kepiting di Pulau Cawan dapat diterapkan dan berkelanjutan, serta produksinya dapat ditingkatkan untuk memenuhi permintaan pasar adalah dengan cara melakukan budidaya kepiting cangkang lunak dan pembuatan pakan berbasis bahan lokal, seperti ekstrak bayam, ikan rucah dan lain-lain sehingga harganya relatif murah, menerapkan teknik tambak dengan adaptasi silvofishery serta pengolahan produk budidaya pasca panen untuk meningkatkan harga jualnya

\section{Tingkat ketercapaian sarana program}

Kegiatan Program Desa Binaan di Desa Pulau Cawan dimulai dengan melakukan pertemuan dan diskusi pada bulan 19 Maret 2020 dengan mitra (Dinas Perikanan dan Kelautan Kabupaten Indragiri Hilir, Kepala Desa Pulau Cawan dan KADIN). Kemudian dilanjutkan pada tanggal 7 Juli 2020 untuk koordinasi mengenai kegiatan yang akan dilaksanakan, persiapan bahan dan alat yang dibutuhkan pada saat pelaksanaan kegiatan, jadwal dan lokasi yang akan dipilih sebagai kolam percontohan (Gambar 1). 
Koordinasi juga dilakukan dengan perangkat Kelurahan, POKDAKAN Dolphin Farm dan Cahaya Utara Mandiri, mahasiswa KUKERTA terintegrasi dan Tim Pengabdian Kepada Masyarakat LPPM Universitas Riau, di kantor Kelurahan. Berdasarkan hasil pertemuan dengan Ibu Kepala Kelurahan Tangkerang Utara Bismiyati, S.H., ketua POKDAKAN Cahaya Utara Mandiri Burhan Budi dan ketua Dolphin Farm Suhendra, disepakati pelaksanaan kegiatan dilakukan pada bulan Juli 2020, penyampaian materi praktek dilakukan pada salah satu rumah anggota POKDAKAN.
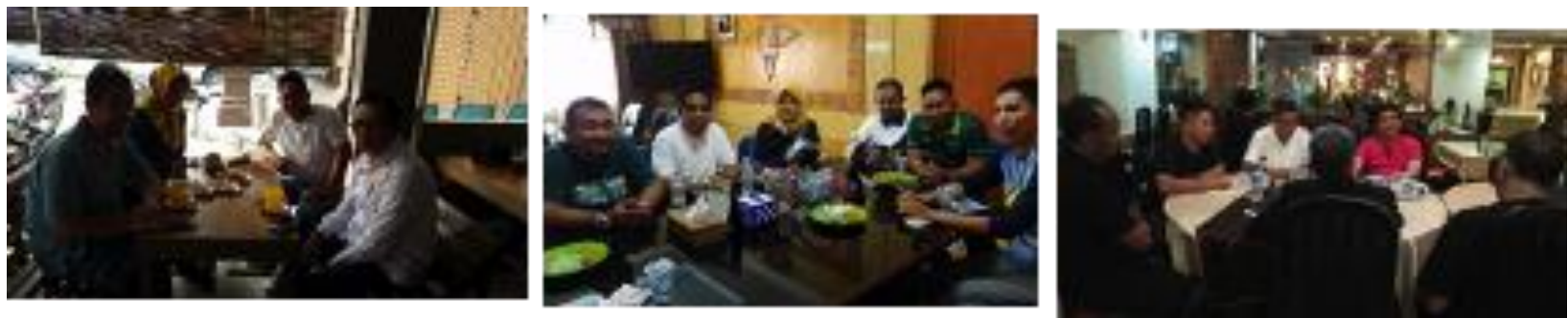

Gambar 1. Koordinasi TIM Desa Binaan dengan Kepala Desa Pulau Cawan, KADIN dan Dinas Perikanan dan Kelautan Kabupaten Indragiri Hilir

Penyampaian materi dilakukan di unit usaha POKDAKAN Pulau Cawan (Gambar 2), penyajian materi penyuluhan diawali dengan pemberian kata sambutan oleh Kepala Desa Pulau Cawan Said Khairul, kemudian pemaparan usaha budidaya oleh Kepala Desa dan ditutup pembacaan doa oleh koordinator kelompok mahasiswa KUKERTA Terintegrasi. Pada kegiatan ini mahasiswa KUKERTA terintegrasi dilibatkan secara aktif. Pada saat penyampaian materi kepada peserta penyuluhan dibagikan modul yang memuat materi yang disampaikan, yaitu mengenai teknik budidaya kepiting soka dengan pakan buatan dari ekstrak bayam, pemilihan bahan baku pakan ikan yang murah, berbasis lokal dan ramah lingkungan, jenis-jenis pakan alami untuk mempercepat molting pada kepiting.

Selama penyampaian materi, peserta penyuluhan juga diberi kesempatan untuk bertanya mengenai materi yang kurang dipahami. Diskusi pada sesi ini berlangsung sangat baik, peserta penyuluhan antusias bertanya ke narasumber, karena materi yang disampaikan masih baru buat mereka.
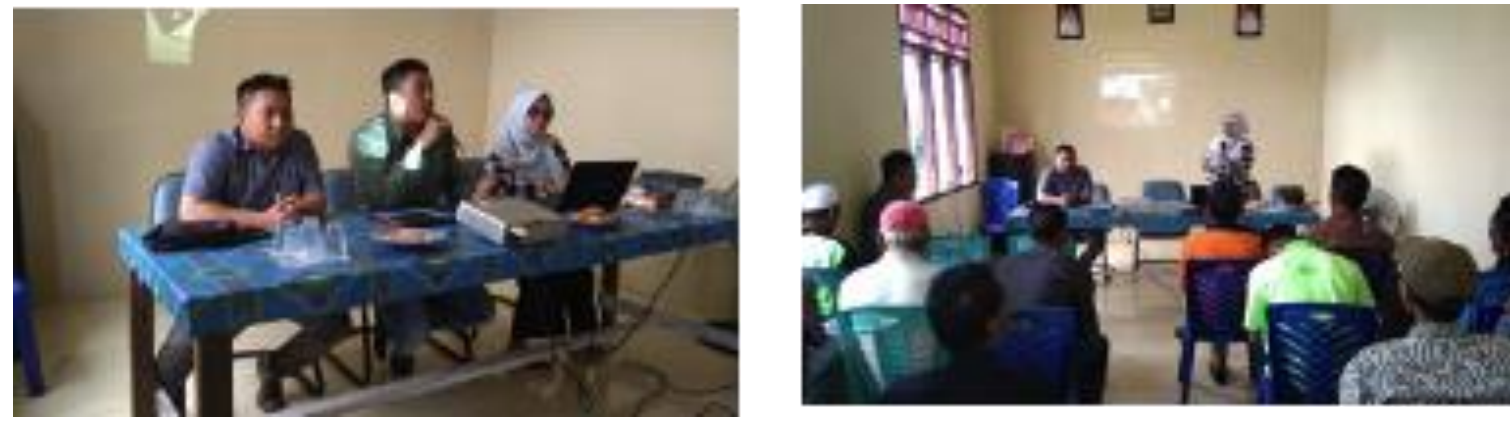

Gambar 2. Penyampaian materi penyuluhan oleh TIM Desa Binaan

Pelaksanaan pembuatan kolam budidaya, pengapuran, pembuatan keramba hingga pembuatan pakan dilaksanakan secara aktif melibatkan anggota POKDAKAN dan TIM KUKERTA TERINTEGRASI yang dibimbing oleh TIM Pengabdian Desa Binaan LPPM UNRI. Kegiatan dimulai dengan melakukan persiapan kolam, pengeringan kolam yang akan digunakan, pengangkatan lumpur dan pengapuran (Gambar 3). Kapur yang diberikan merupakan kapur dolomit. Sebanyak $200 \mathrm{gr} / \mathrm{m}^{3}$, kemudian ditambahkan garam krosok (nonyodium) $3 \mathrm{~kg} / \mathrm{m}^{3}$ air. 

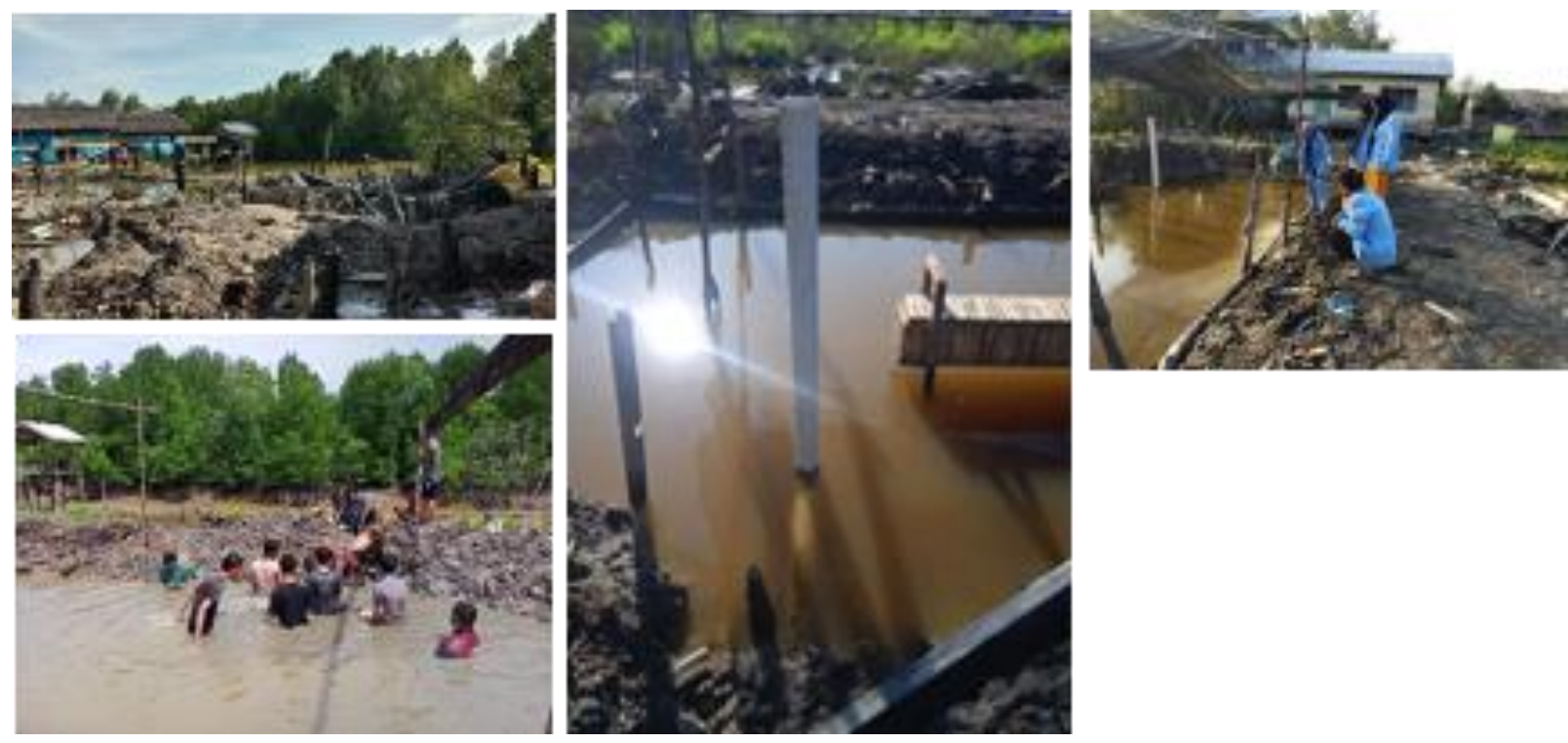

Gambar 3. Persiapan kolam oleh anggota POKDAKAN melibatkan mahasiswa KUKERTA terintegrasi untuk melakukan pelatihan di lapangan

Setelah pembuatan tambak dan melakukan pengapuran, dilanjutkan dengan pembuatan keramba berbahan dasar bambu. Ini dilakukan sebagai bahan pengganti crab box yang harganya cukup mahal dan harus dibeli dalam jumlah yang sangat banyak. (Gambar 4).
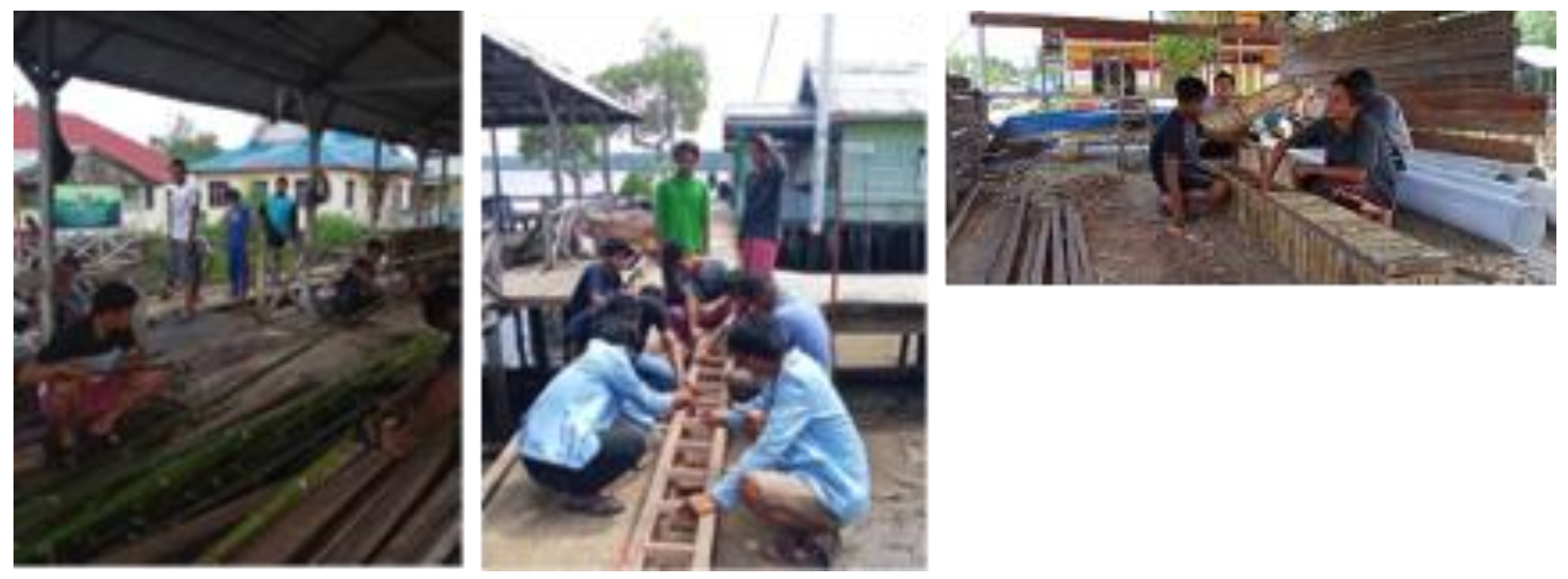

Gambar 4. Pembuatan keramba berbahan dasar bambu

Keramba yang telah selesai dirakit kemudian dipasang ke dalam tambak yang telah disiapkan. Sebelum keramba dimasukkan pada tambak dipasang 3 batang kayu balok dengan posisi sejajar yang berfungsi sebagai tiang penyangga keramba. Selanjutnya letakkan keramba ke tiang penyangga dan diberi pelampung. Hasil dari kegiatan pembuatan keramba (Crab Boxes) menghasilkan dua tempat keramba yang pertama panjang keramba 5 Meter dan tinggi $25 \mathrm{~cm}$, yang memiliki 20 kotak sekat atau bilik dan yang kedua memiliki 25 kotak sekat atau bilik (Gambar 5) 

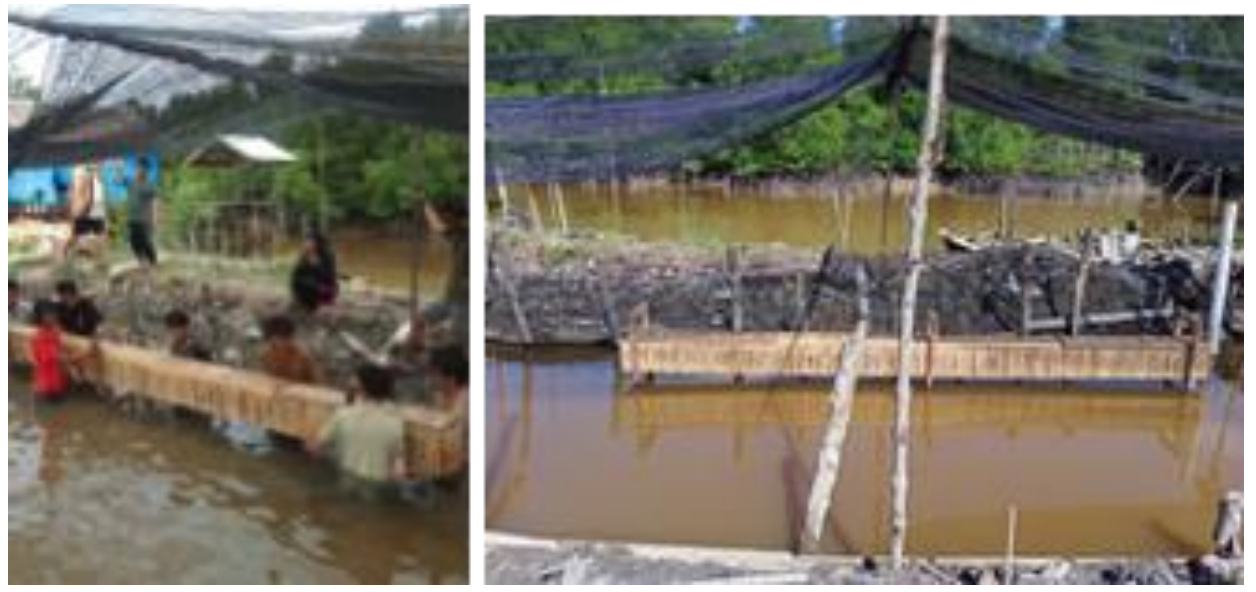

Gambar 5. Pemasangan Keramba ke dalam tambak kepiting

Pembuatan pakan dengan melibatkan anggota POKDAKAN, istri petambak bersama mahasiswa KKN pakan, dimulai dengan pengumpulan bahan-bahan pakan seperti daun bayam, kapur $\mathrm{CaCo} 2$, ikan rucah dan tepung tapioka sebagai perekat (Gambar 6).
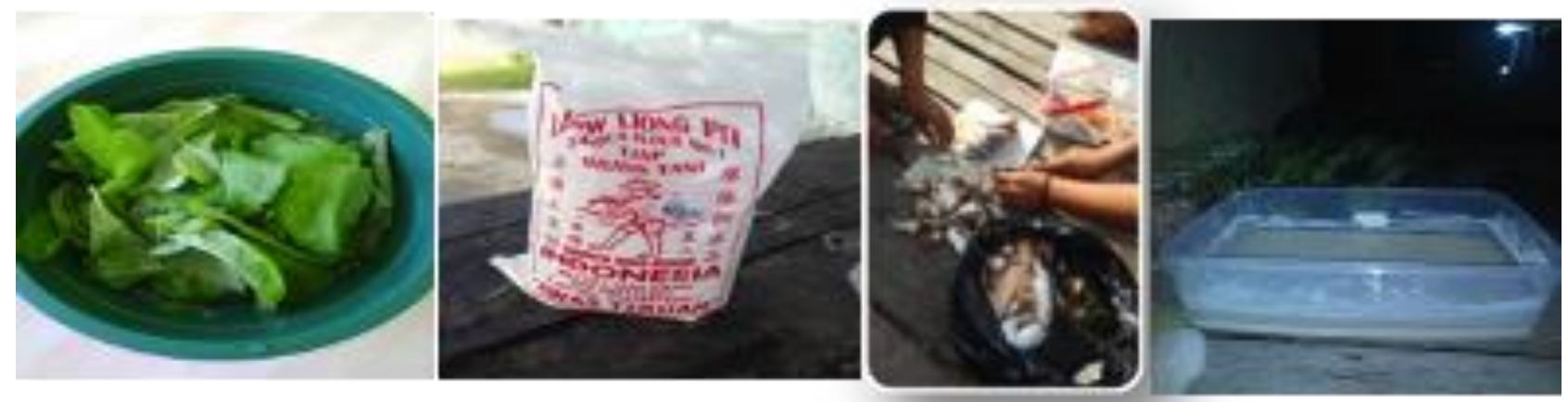

Gambar 6. Bahan Pakan

Selanjutnya dilakukan pembuatan pakan dengan mencampur semua bahan setelah dilakukan pengeringan terhadap daun bayam untuk dijadikan ekstrak (Gambar 7).
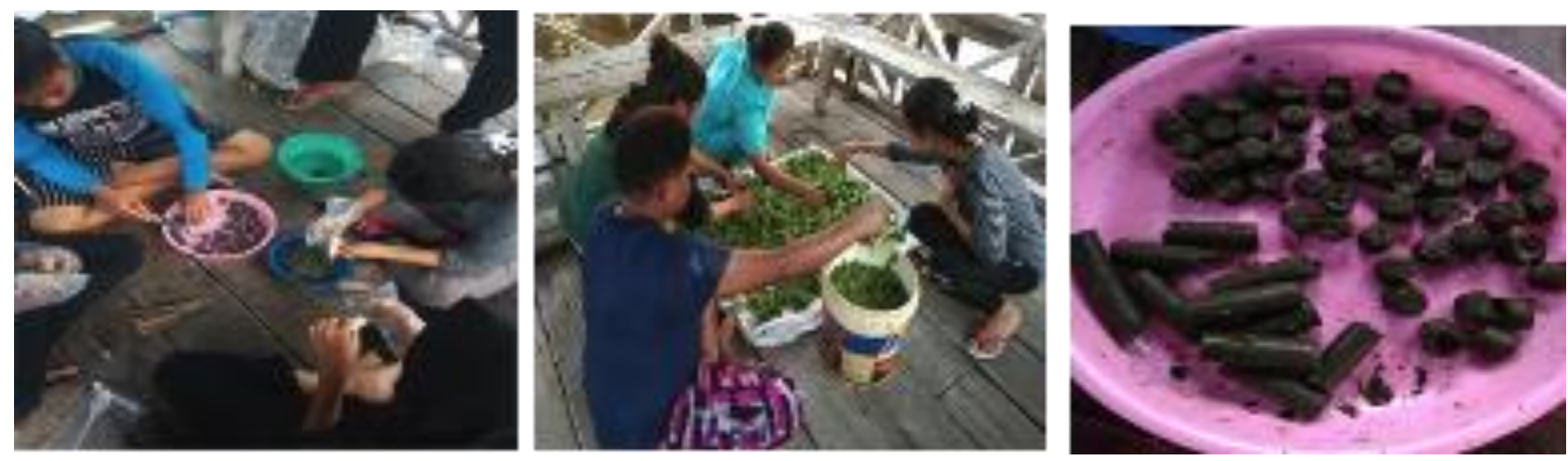

Gambar 7. Proses pembuatan pakan alami ekstrak bayam

\section{Evaluasi}

Hasil evaluasi proses menunjukkan selama praktek seluruh peserta penyuluhan terlibat secara langsung pada setiap tahap yang dikerjakan dan terlihat bersemangat dalam mengikuti setiap tahapan kegiatan yang dilakukan. Setelah praktek terlihat seluruh peserta sudah dapat melakukan teknik yang diberikan secara mandiri. 
Hasil evaluasi peningkatan pengetahuan terhadap 24 orang peserta penyuluhan menunjukkan belum pernah mengenal tentang pembuatan pakan alami dari campuran ekstrak bayam, air kapur dan ikan rucah Setelah mengikuti kegiatan pelatihan ini terjadi peningkatan pengetahuan tentang aplikasi probiotik ini sebesar 86,96\%. 22 orang peserta telah memahami tentang bahan dan cara membuat pakan, dan seluruh peserta telah mengetahui manfaat dari pakan alami. Penilaian mitra terhadap pelaksanaan kegiatan ini adalah: 52,17 sangat setuju pembuatan pakan dapat dilakukan secara mandiri, 52,17\% sangat setuju pemberian air kapur dan ekstrak bayam terhadap campuran pakan buatan ikan rucah berpengaruh terhadap percepatan proses molting pada kepiting dan tidak berpengaruh terhadap kelulushidupan kepiting; $60,87 \%$ sangat setuju dapat menjadi alternatif mata pencaharian dan $65,22 \%$ sangat setuju proses molting pada budidaya kepiting cangkang lunak sama dengan saat kepiting diberi vitamolt yaitu 20 hari.

\section{KESIMPULAN}

Pembuatan pakan alami dari ekstrak bayam, air kapur dan ikan rucah di Desa Pulau Cawan Kecamatan Mandah dapat diterima dengan baik. Hasil evaluasi yang dilakukan sebelum dan setelah dilakukannya kegiatan penyuluhan ada peningkatan pengetahuan dan keterampilan pembudidaya ikan di desa ini. Peserta umumnya sangat setuju dengan pelaksanaan kegiatan ini. Peningkatan pengetahuan dan keterampilan pembudidaya kepiting dalam pembuatan pakan alami dapat menjadi bekal agar kegiatan budidaya ini dapat terus berlanjut, dan Desa Pulau Cawan ini dapat menjadi daerah percontohan untuk daerah sekitarnya beberapa tahun ke depan. Kendala yang dihadapi TIM desa binaan adalah sulit untuk melakukan pendampingan untuk kelanjutan pembuatan pakan secara tatap muka terhadap mitra karena adanya pandemi Covid-19, sehingga tidak berjalan secara maksimal.

\section{UCAPAN TERIMA KASIH}

Ucapan terima kasih dihaturkan kepada Lembaga Penelitian dan Pengabdian Masyarakat Universitas Riau selaku pemberi dana, Kepala Desa Pulau Cawan, Kepala Dinas PErikanan dan Kelautan Kabupaten Indragiri Hilir, Kepala BAPPEDA Kabupaten Indragiri Hilir, Riza Pahlivi, S.Pi., M.Si, POKDAKAN Pulau Cawan, POKDAKAN Pantai Solop, mahasiswa kukerta terintegrasi yang telah berkontribusi besar dalam pelaksanaan kegiatan ini.

\section{DAFTAR PUSTAKA}

Ansari, G. dan S. Sulaiman. 2010. Metode Pengukuran Kualitas Air. Usaha Nasional. Surabaya.

Fujaya, Y., D. D. Trijuno, \& E. Suryati. 2008. Pengembangan Teknologi Produksi Rajungan Lunak Hasil Pembenihan dengan Memanfaatkan Ekstrak Bayam Sebagai Stimulan Molting. Laporan Penelitian Tahun II, RISTEKprogram insentif riset terapan, Menristek, Fakultas Ilmu Kelautan dan Perikanan, Universitas Hasanuddin. Makassar.

Kanna, I. 2002. Budidaya Kepiting Bakau Pembenihan dan Pembesaran. Kansius. Yogyakarta. 